\title{
Cation Effects on ORR Activity on Low-index Planes of Pd in Alkaline Solution
}

\section{Fumiya KIGUCHI, Masashi NAKAMURA, and Nagahiro HOSHI ${ }^{*}$ *}

Department of Applied Chemistry and Biotechnology, Graduate School of Engineering, Chiba University, 1-33 Yayoi-cho, Inage-ku, Chiba 263-8522, Japan

*Corresponding author: hoshi@faculty.chuiba-u.jp

\section{ABSTRACT}

The oxygen reduction reaction (ORR) has been studied on low-index planes of $\mathrm{Pd}$ in $0.05 \mathrm{M} \mathrm{XOH} \mathrm{(X=Li,} \mathrm{Na,} \mathrm{K}$, and $\mathrm{Cs}$ ) solutions to determine the effects of cations on ORR activity. The order of ORR activity is $\mathrm{Pd}(110)<\mathrm{Pd}(100)<\mathrm{Pd}(111)$ in all solutions. This order differs from that in $\mathrm{HClO}_{4}: \operatorname{Pd}(110)<\mathrm{Pd}(111) \ll \mathrm{Pd}(100)$. Cationic species do not affect the ORR activity on $\mathrm{Pd}(110)$ and $\mathrm{Pd}(100)$. In contrast, the ORR activity of $\mathrm{Pd}(111)$ increases in the order of $\mathrm{Li}^{+}<\mathrm{Na}^{+}<\mathrm{K}^{+}<\mathrm{Cs}^{+}$. The lower the cation hydration energy, the higher the ORR activity on $\mathrm{Pd}(111)$, as is also the case on $\mathrm{Pt}(111)$. The ORR activity of $\mathrm{Pd}(111)$ in $\mathrm{CsOH}$ is 1.8 times higher than that of $\mathrm{Pd}(100)$ in $\mathrm{HClO}_{4}$.

(C) The Author(s) 2021. Published by ECSJ. This is an open access article distributed under the terms of the Creative Commons Attribution 4.0 License (CC BY, http://creativecommons.org/licenses/by/4.0/), which permits unrestricted reuse of the work in any medium provided the original work is properly cited. [DOI: 10.5796/electrochemistry.21-00008].

Keywords : Oxygen Reduction Reaction, Alkaline Solutions, Low-index Planes of Pd, Structural Effects

\section{Introduction}

$\mathrm{Pt}$ is widely used as an electrocatalyst in polymer electrolyte fuel cells (PEFCs). Large amounts of expensive and rare Pt are loaded in an air electrode because of the high overpotential of the oxygen reduction reaction (ORR). It is necessary to develop new ORRactive electrocatalysts to reduce Pt loading.

The activity and selectivity of electrochemical reactions depend markedly on the surface structures of the electrodes. ${ }^{1-3}$ One method used to increase ORR activity is to adjust the surface structure on the atomic scale. Marković et al. reported that ORR activity increases in the order of $\mathrm{Pt}(100)<\mathrm{Pt}(111)<\mathrm{Pt}(110)$ in $0.1 \mathrm{M} \mathrm{HClO}_{4}{ }^{4}$ The ORR activity series of low-index planes of Pd differs from that of Pt: $\operatorname{Pd}(110)<\operatorname{Pd}(111)<\operatorname{Pd}(100) .{ }^{5}$ The ORR activity of $\operatorname{Pd}(100)$ is also three times higher than that of $\operatorname{Pt}(110)$.

In addition to the surface structure, surface oxides and ionic species at the solid-liquid interface affect the ORR activity. ${ }^{6}$ Alkali metal cations have stable hydration structure and exist as nonspecific adsorbed ions on the outer Helmholtz plane. ${ }^{6-10}$ The ORR activity of $\mathrm{Pt}(111)$ in $0.1 \mathrm{M} \mathrm{XOH}(\mathrm{X}=\mathrm{Li}, \mathrm{Na}, \mathrm{K}$, and $\mathrm{Cs})$ increases in the order of $\mathrm{Li}^{+}<\mathrm{Na}^{+}<\mathrm{K}^{+}<\mathrm{Cs}^{+}$: low cation hydration energies yield higher activity. However, the ORR activity on single-crystal electrodes of Pd in alkaline solutions has not been reported. In this communication, we describe the ORR on the low-index planes of $\mathrm{Pd}$ ( $\mathrm{Pd}(111), \mathrm{Pd}(100)$ and $\mathrm{Pd}(110))$ in $\mathrm{XOH}(\mathrm{X}=\mathrm{Li}, \mathrm{Na}, \mathrm{K}$, and $\mathrm{Cs})$ to clarify the cation effects on ORR activity.

\section{Experimental}

$\mathrm{LiOH} \cdot \mathrm{H}_{2} \mathrm{O}(99.995 \%), \mathrm{NaOH}(\geq 98 \%), \mathrm{KOH}(99.99 \%)$, and $\mathrm{CsOH} \cdot \mathrm{H}_{2} \mathrm{O}(99.95 \%)$ were purchased from Sigma-Aldrich. $\mathrm{H}_{2} \mathrm{SO}_{4}$ (Ultrapur) was purchased from Kanto Chemical Corporation. Ultrapure water was produced using Milli-Q Advantage A10 (Millipore). Ultrapure Ar gas (>99.9999\%) was used for cooling Pd single-crystal electrodes after annealing.

A single-crystal bead of Pd with a diameter of about $3 \mathrm{~mm}$ was prepared by a modified Clavilier method. ${ }^{11,12}$ The single crystal was oriented using the reflected beam of a $\mathrm{He} / \mathrm{Ne}$ laser. Hard sphere

N. Hoshi (D) orcid.org/0000-0001-5808-580X

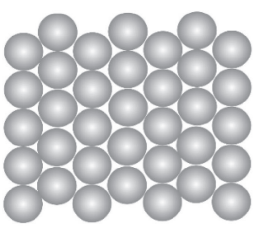

(111)

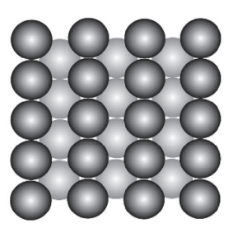

(110)

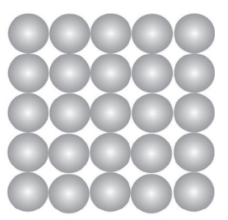

(100)
Figure 1. Hard sphere models of $\operatorname{Pd}(111), \operatorname{Pd}(110)$, and $\operatorname{Pd}(100)$.

models of the single-crystal electrodes examined are shown in Fig. 1. The oriented single crystal was mechanically polished with a diamond slurry. Before electrochemical measurements, the singlecrystal electrodes were annealed with a $\mathrm{H}_{2}-\mathrm{O}_{2}$ flame at approximately $1300^{\circ} \mathrm{C}$ to remove distortions due to the mechanical polishing. After annealing, the single-crystal electrodes were cooled to room temperature in an Ar atmosphere, and their surfaces were protected with ultrapure water.

Electrochemical measurements were carried out using an electrochemical analyzer (ALS 701D). All potentials were referenced to the reversible hydrogen electrode (RHE).

Linear sweep voltammograms were measured using RRDE-3 (BAS) in the hanging meniscus rotating electrode (HMRDE) configuration. ${ }^{13}$ Potentials were scanned in the positive direction from 0.2 to $1.0 \mathrm{~V}$ (vs. RHE) at a rotation rate of $1600 \mathrm{rpm}$. ORR activity $\left(j_{\mathrm{K}}\right)$ was calculated at $0.90 \mathrm{~V}$ (vs. RHE) using the Koutecky-Levich equation. ${ }^{14,15}$

$$
\frac{1}{j}=\frac{1}{j_{K}}+\frac{1}{j_{L}}
$$

where $j, j_{\mathrm{K}}$, and $j_{\mathrm{L}}$ represent the total current density, kinetic current density, and limiting current density, respectively.

\section{Results and Discussion}

Figures 2(a)-2(c) show voltammograms of the low-index planes of $\mathrm{Pd}$ in $0.5 \mathrm{M} \mathrm{H}_{2} \mathrm{SO}_{4}$ solution saturated with Ar. The voltammograms are identical to those reported previously; ${ }^{11}$ the surface is 

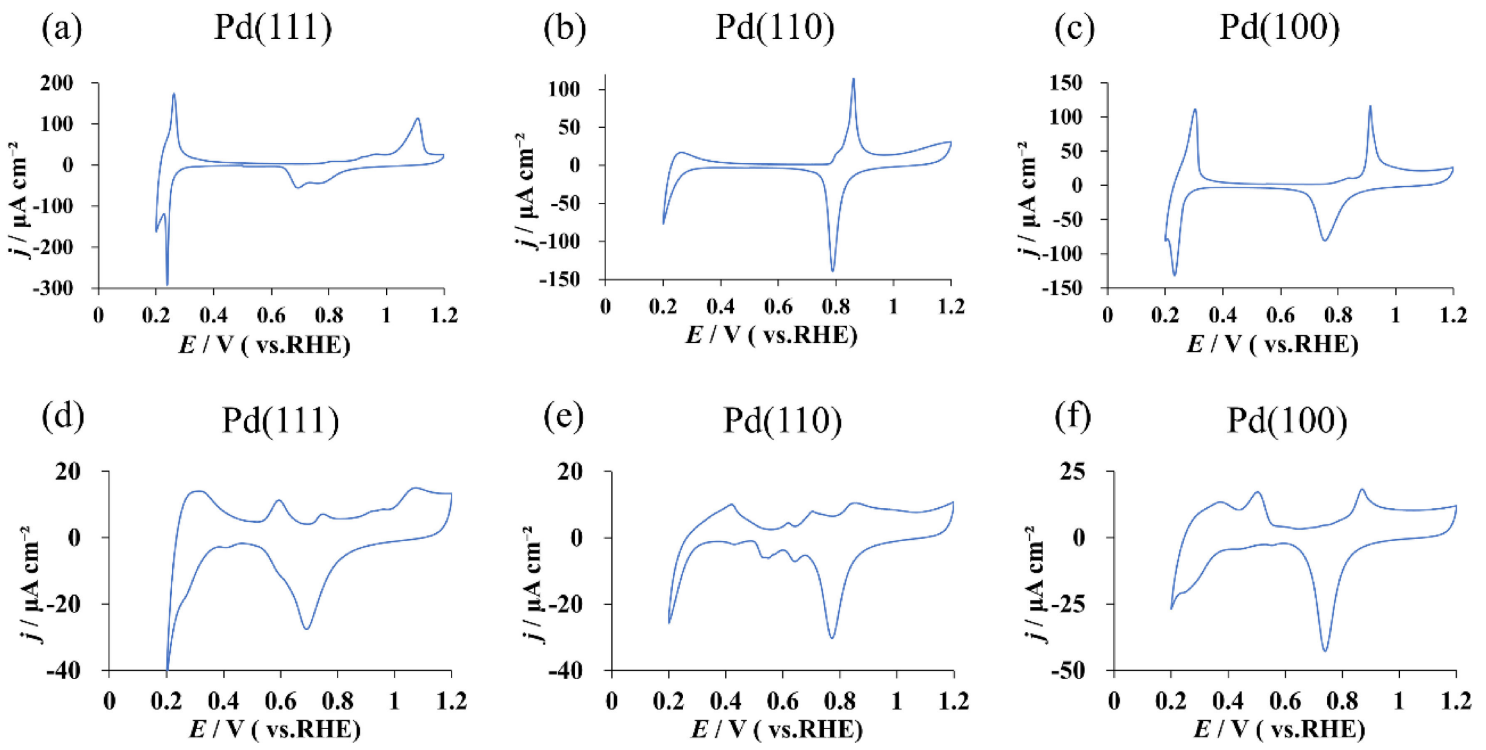

Figure 2. Voltammograms of Pd in Ar-saturated solutions. Upper panels show voltammograms of $\operatorname{Pd}(111)(\mathrm{a}), \operatorname{Pd}(110)(\mathrm{b})$, and $\operatorname{Pd}(100)(\mathrm{c})$ in $0.5 \mathrm{M} \mathrm{H}_{2} \mathrm{SO}_{4}$ at a scanning rate $0.020 \mathrm{~V} \mathrm{~s}^{-1}$. Lower panels show voltammograms of $\mathrm{Pd}(111)(\mathrm{d}), \mathrm{Pd}(110)(\mathrm{e})$, and $\mathrm{Pd}(100)(\mathrm{f})$ in $0.05 \mathrm{M}$ $\mathrm{KOH}$ at a scanning rate $0.01 \mathrm{~V} \mathrm{~s}^{-1}$.

correctly oriented. In situ surface X-ray scattering (SXS) analysis showed that the $\mathrm{Pd}$ single crystal electrodes have $(1 \times 1)$ structures. ${ }^{16,17}$

Figures 2(d)-2(f) show voltammograms of the low-index plane in $0.05 \mathrm{M} \mathrm{KOH}$ saturated with Ar. The anodic peak at $0.5 \mathrm{~V}$ (vs. RHE) of $\operatorname{Pd}(100)$ is due to the release of the absorbed hydrogen, and the other anodic peak is due to oxide formation. ${ }^{18}$ The anodic peaks above $0.6 \mathrm{~V}$ (vs. RHE) on $\mathrm{Pd}(111)$ and $\mathrm{Pd}(110)$ are also due to oxide formation. ${ }^{18}$ Similar voltammograms were obtained in other alkaline solutions. Detailed analyses of the peaks were reported previously. ${ }^{18}$

Liner sweep voltammograms in $\mathrm{O}_{2}$-saturated solutions are shown in Figs. 3(a)-3(d). The ORR activities $\left(j_{\mathrm{K}}\right)$ at $0.90 \mathrm{~V}$ (vs. RHE) are summarized in Fig. 3(e). The ORR activity increases in the order of $\operatorname{Pd}(110)<\operatorname{Pd}(100)<\operatorname{Pd}(111)$ in all the solutions. The order of the ORR activity of $\operatorname{Pd}(111)$ and $\operatorname{Pd}(100)$ in alkaline solutions is opposite to that in $0.1 \mathrm{M} \mathrm{HClO}_{4}: \operatorname{Pd}(110)<\operatorname{Pd}(111)<\operatorname{Pd}(100){ }^{5}$ The ORR activity of $\mathrm{Pd}(111)$ in $\mathrm{CsOH}$, which is the highest in this study, was 1.8 times higher than that of $\operatorname{Pd}(100)$, which has the highest activity in $\mathrm{HClO}_{4}$. In the case of Pt electrodes, the orders of ORR activity were $\mathrm{Pt}(100)<\mathrm{Pt}(111)<\mathrm{Pt}(110)$ in $0.1 \mathrm{M} \mathrm{HClO}_{4}{ }^{4}$ and $\operatorname{Pt}(100)<\operatorname{Pt}(110)<\operatorname{Pt}(111)$ in $0.1 \mathrm{M} \mathrm{KOH} .{ }^{19}$ These orders differ from those of Pd. However, the ORR activity on the (111) plane is the highest in the low-index planes of Pd and Pt in alkaline solutions.

The ORR activity of $\operatorname{Pd}(111)$ increases in the order of $\mathrm{Li}^{+}<\mathrm{Na}^{+}<\mathrm{K}^{+}<\mathrm{Cs}^{+}$. The order is the same as that of $\operatorname{Pt}(111)$. The ORR activity increases with decreasing hydration energy of the cation, as is also the case on $\operatorname{Pt}(111) .{ }^{6}$ However, no such cation dependence is found on $\operatorname{Pd}(100)$ or (110).

On Pt electrodes, the ORR activity decreases with increasing coverage of Pt oxides. ${ }^{20-23}$ The charge of Pd oxides $(Q)$ at $0.90 \mathrm{~V}$ (vs. RHE) was calculated from the orange areas of the voltammograms in Fig. S1. Currents generated with the release of absorbed hydrogen continued up to $0.6 \mathrm{~V}$ (vs. RHE); charges associated with Pd oxide formation were estimated from voltammograms between 0.5 and $1.2 \mathrm{~V}$ (vs. RHE) in this voltage range no hydrogen was absorbed. The ORR activity is plotted against $Q$ in Fig. S2. No correlation was found between $Q$ and ORR activity. On the low-
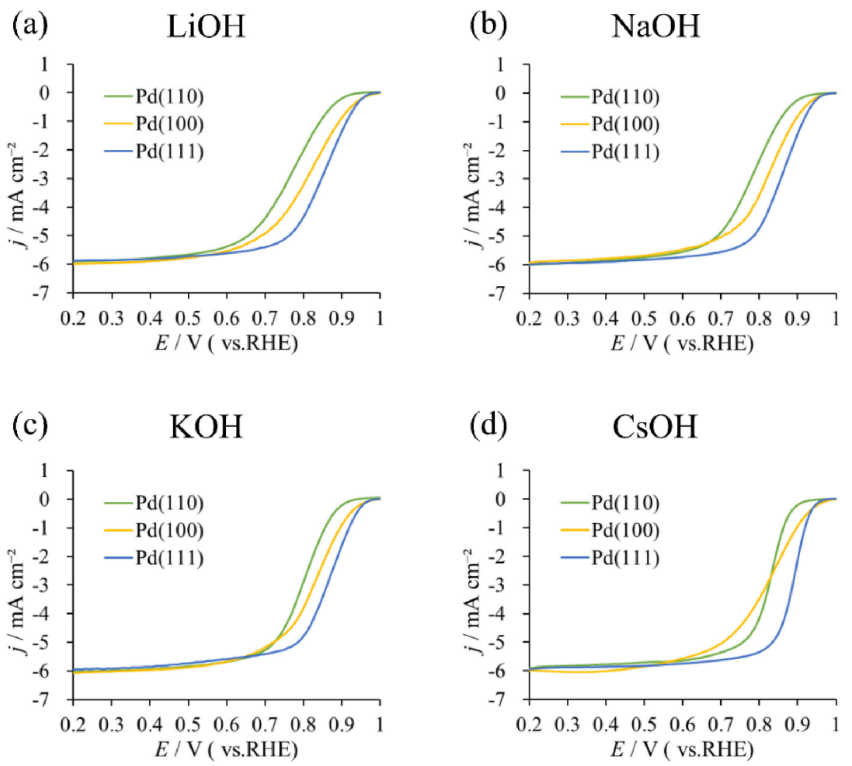

(d) $\quad \mathrm{CsOH}$

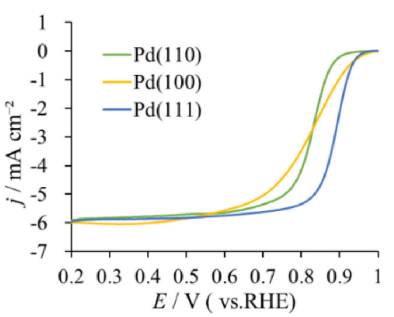

(e)

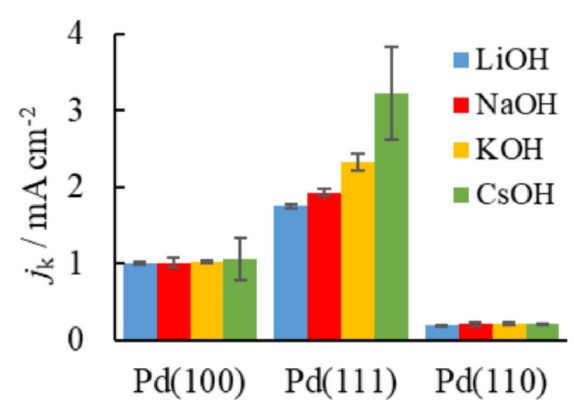

Figure 3. Linear sweep voltammograms of $\mathrm{Pd}$ in $\mathrm{O}_{2}$-saturated solutions at a rotation rate of $1600 \mathrm{rpm}$ and sweep rate of $0.010 \mathrm{~V} \mathrm{~s}^{-1}$. Plots (a), (b), (c), and (d) show the results in $0.05 \mathrm{M}$ $\mathrm{LiOH}, \mathrm{NaOH}, \mathrm{KOH}$ and $\mathrm{CsOH}$, respectively. Plot (e) shows ORR activities $\left(j_{\mathrm{K}}\right)$ at $0.90 \mathrm{~V}$ (vs. RHE). 
index planes of Pt, $\mathrm{PtOH}$ is blocks the ORR. ${ }^{21,22}$ However, PtO hinders the ORR on only $\operatorname{Pt}(100) .^{23}$ No correlation was found between the band intensity of surface-enhanced Raman spectroscopy (SERS) of $\mathrm{PtO}$ and the ORR activity on $\mathrm{Pt}(111)$ and $\mathrm{Pt}(110) .{ }^{23} \mathrm{It}$ is likely that $\mathrm{PdOH}$ and $\mathrm{PdO}$ are both adsorbed at $0.90 \mathrm{~V}$ (vs. RHE). Only $\mathrm{PdOH}$ or $\mathrm{PdO}$ may affect the ORR on Pd electrodes. Vibrational spectroscopy is necessary to elucidate which Pd oxides deactivate the ORR.

Alkali metal cations affect the ORR on $\operatorname{Pd}(111)$, but not on $\operatorname{Pd}(100)$ and $\operatorname{Pd}(110)$. One of the factors other than Pd oxides that affect the ORR is the structure of adsorbed water. On the low-index planes of Pt modified with alkylamines, the cluster size of ice like water (multilayer of hexamer water) affects the ORR activity markedly. ${ }^{24}$ According to studies in ultra-high vacuum (UHV), hexametric water molecules are found on $\operatorname{Pt}(111){ }^{25}$ The hexamer water structure is also formed on $\operatorname{Pd}(111)$, the atomic arrangement of which is hexagonal. ${ }^{26} \mathrm{On} \operatorname{Pd}(100)$ and $\operatorname{Pd}(110)$, hexametric water is hardly ever formed because the symmetry of the surface structures differs from that of hexametric water. The absence of hexametric water structure may be responsible for the absence of an alkali metal cation effect on $\operatorname{Pd}(100)$ and $\operatorname{Pd}(110)$.

Studies on Pd oxides and adsorbed water are now in progress in our laboratory using vibrational spectroscopy to elucidate the detailed mechanism underlying the alkali cation effects on the ORR.

\section{Conclusions}

The ORR activity in $0.05 \mathrm{M}$ XOH $(\mathrm{X}=\mathrm{Li}, \mathrm{Na}, \mathrm{K}, \mathrm{Cs})$ increases in the order of $\operatorname{Pd}(110)<\operatorname{Pd}(100)<\operatorname{Pd}(111)$. This order differs from that in $\mathrm{HClO}_{4}$ : $\operatorname{Pd}(110)<\operatorname{Pd}(111)<\operatorname{Pd}(100)$. The ORR activity of $\mathrm{Pd}(111)$ in $\mathrm{CsOH}$ is 1.8 times higher than that of $\mathrm{Pd}(100)$ in $\mathrm{HClO}_{4}$. Alkali metal cations affect the ORR activity of $\operatorname{Pd}(111): \mathrm{Li}^{+}<\mathrm{Na}^{+}<\mathrm{K}^{+}<\mathrm{Cs}^{+}$. In contrast, there is no effect of cations on $\operatorname{Pd}(110)$ and $\operatorname{Pd}(100)$. No correlation is found between the ORR activity and the total charge of Pd oxide formation at $0.90 \mathrm{~V}$ (vs. RHE).

\section{Supporting Information}

The Supporting Information is available on the website at DOI: https://doi.org/10.5796/electrochemistry.21-00008.

\section{Acknowledgment}

This work was partially supported by the New Energy Development Organization (NEDO).

\section{References}

1. C. Lamy and J. M. Leger, J. Chim. Phys., 88, 1649 (1991).

2. N. M. Marković and P. N. Ross, Jr., Surf. Sci. Rep., 45, 117 (2002).

3. S. Ye, T. Kondo, N. Hoshi, J. Inukai, S. Yoshimoto, M. Osawa, and K. Itaya, Electrochemistry, 77, 2 (2009).

4. N. M. Marković, R. R. Adžić, B. D. Cahan, and E. B. Yeager, J. Electroanal. Chem., 377, 249 (1994).

5. S. Kondo, M. Nakamura, N. Maki, and N. Hoshi, J. Phys. Chem. C, 113, 12625 (2009).

6. D. Strmcnik, K. Kodama, D. van der Vliet, J. Greeley, V. R. Stamenkovic, and N. M. Marković, Nat. Chem., 1, 466 (2009).

7. D. Strmenik, D. F. Van Der Vliet, K. C. Chang, V. Komanicky, K. Kodama, H. You, V. R. Stamenkovic, and N. M. Marković, J. Phys. Chem. Lett., 2, 2733 (2011).

8. W. Jin, H. Du, S. Zheng, H. Xu, and Y. Zhang, J. Phys. Chem. B, 114, 6542 (2010).

9. D. J. Miller and J. M. Lisy, J. Am. Chem. Soc., 130, 15393 (2008).

10. D. J. Miller and J. M. Lisy, J. Am. Chem. Soc., 130, 15381 (2008).

11. N. Hoshi, K. Kagaya, and Y. Hori, J. Electroanal. Chem., 485, 55 (2000)

12. J. Clavilier, R. Faure, G. Guinet, and R. Durand, J. Electroanal. Chem., 107, 205 (1980).

13. B. D. Cahan and H. M. Villullas, J. Electroanal. Chem., 307, 263 (1991).

14. H. M. Villullas and M. L. Teijelo, J. Electroanal. Chem., 384, 25 (1995).

15. H. M. Villullas and M. L. Teijelo, J. Electroanal. Chem., 385, 39 (1995).

16. K. Naito, M. Nakamura, O. Sakata, and N. Hoshi, Electrochemistry, 79, 256 (2011).

17. N. Hoshi, K. Naito, M. Nakamura, and O. Sakata, Electrochemistry, 82, 351 (2014).

18. N. Hoshi, M. Nakamura, N. Maki, S. Yamaguchi, and A. Kitajima, J. Electroanal. Chem., 624, 134 (2008).

19. N. M. Marković, H. A. Gasteiger, and P. N. Ross, J. Phys. Chem., 100, 6715 (1996).

20. N. M. Marković, H. A. Gasteiger, B. N. Grgur, and P. N. Ross, J. Electroanal. Chem., 467, 157 (1999).

21. H. Tanaka, S. Sugawara, K. Shinohara, T. Ueno, S. Suzuki, N. Hoshi, and M. Nakamura, Electrocatalysis, 6, 295 (2015).

22. T. Ueno, H. Tanaka, S. Sugawara, K. Shinohara, A. Ohma, N. Hoshi, and M. Nakamura, J. Electroanal. Chem., 800, 162 (2017).

23. F. Sugimura, N. Sakai, T. Nakamura, M. Nakamura, K. Ikeda, T. Sakai, and N. Hoshi, Phys. Chem. Chem. Phys., 19, 27570 (2017).

24. K. Saikawa, M. Nakamura, and N. Hoshi, Electrochem. Commun., 87, 5 (2018).

25. M. Nakamura and M. Ito, Chem. Phys. Lett., 404, 346 (2005).

26. T. Mitsui, M. K. Rose, E. Fomin, D. F. Ogletree, and M. Salmeron, Science, 297, 1850 (2002). 